\title{
Funkcja semantyczna stroju na przykładzie portretów i fotografii ziemian polskich
}

\begin{abstract}
Die Semiologie der Kleidung spielt in der gesellschaftlichen Kommunikation eine wichtige Rolle. Diese Rolle wurde auf eine besondere Art und Weise bewusst im Kreis der Gutsbesitzer ausgenutzt. Durch Kleidung wollte man sowohl nationale und patriotische Inhalte als auch die mit Religiosität und Tradition verbundenen fördern
\end{abstract}

Key words: Semiologie, Gutsbesitzer, Kleidung

„Nam ubiór niedbały nie przystoi”. Pod takim tytułem Muzeum Historii Fotografii w Krakowie zorganizowało w 2003 roku wystawę, na której zaprezentowane zostały fotografie portretowe, głównie ziemian polskich $^{1}$. Nawet pobieżne zerknięcie na te pozowane zdjęcia wyraźnie wskazuje na dość charakterystyczną (bo na ziemiach polskich powszechną) rolę jaką wśród ziemiaństwa pełnił strój. Głębsza i sięgająca daleko poza obręb wystawy analiza zachowanych portretów, zdjęć portretowych oraz fotografii dokumentalnej potwierdza tę hipotezę: strój dla ziemian miał znaczenie propagandowo-edukacyjne. Poprzez

1 Nam ubiór niedbały nie przystoi. Katalog wystawy, oprac. L. Król, M. Skrejko, Kraków 2003, passim. 
ubiór uzewnętrzniano zarówno przekonania patriotyczne i narodowe, jak i religijne.

Jedną z form manifestowania swoich przekonań było zakładanie w czasie ważnych uroczystości (zarówno tych o charakterze społecznym, narodowym, religijnym jak i zupełnie prywatnym) tzw. stroju narodowego. Za taki powszechnie uważa się kontusz i żupan. Strój taki często nazywany jest strojem szlacheckim, należy jednak pamiętać, że w kontuszach chodzili zarówno królowie, magnaci i szlachta jak i patrycjat miejski².

Podstawowym elementem stroju uważanego za tradycyjny ubiór polski jest żupan. Upowszechnił się na ziemiach polskich w XVI wieku, choć sama nazwa skrystalizowała się dopiero pod koniec tegoż wieku. Mógł stanowić zarówno ubiór spodni jak i wierzchni, przy czym w tej ostatniej sytuacji występował w okolicznościach mniej oficjalnych np. w zaciszu domowym. Zgodnie ze zwyczajem obowiązującym we wschodnich odpowiednikach żupana, prawą jego połę zakładano na lewą ${ }^{3}$. Strojem wierzchnim był natomiast kontusz. W kulturze polskiej od momentu pojawienia się na początku Xvıı wieku zyskał on sobie miano najbardziej rozpoznawalnego, reprezentacyjnego i najpowszechniej używanego ubioru. Najbardziej charakterystycznym elementem kontusza jest krój. Przeprute i odrzucone do tyłu rękawy (wyloty) potocznie uważa się za znak rozpoznawczy kontusza. Nie były one jednak wyłączną cechą tego stroju, występowały także w innych

2 Ziemianie. Pomiędzy rzeczywistością a wspomnieniem, oprac. A. Wolska, Kraków 1998, passim; L. Rotter, Ubiór jako wyróżnik przynależności do związków i organizacji na przykładzie bractw kurkowych [w:] Znak, symbol a rituál ako forma společnej komunikácie, Prešov 2012, s. 119-140; I. Turnau, Odzież mieszczaństwa warszawskiego w XVIII w., Wrocław-Warszawa-Kraków 1967, passim.

3 L. Rotter, Leksykon strojów i mundurów bractw kurkowych w Polsce, Kraków 2011, s. 9-34; M. Bartkiewicz, Odzież i wnętrza domów mieszczańskich $w$ Polsce $w$ drugiej połowie XVI i w XVII wieku, Wrocław-Warszawa-Kraków-Gdańsk 1974, passim; Taż, Polski ubiór do 1864 roku, Wrocław 1979, passim; I. Turnau, Ubiór narodowy w dawnej Rzeczypospolitej, Warszawa 1991, s. 17. 
ubiorach, zawsze stanowiąc jednak niezwykle dekoracyjny element. Cechą kontusza są natomiast jednolicie skrojone plecy w formie pionowego pasa i doszyte do niego kloszowe boki suto fałdowane w linii stanu. Kontusze mogły być podbijane futrem lub wykańczane szamerunkiem, zawsze jednak sięgały mniej więcej do połowy łydki. Nie był zapinany, wymagał zatem przepasania. Pod koniec XvıII wieku pojawiły się także nieco lżejsze od kontusza formy odzieży wierzchniej. Zbliżone krojem do kontuszy były czachmany. Z kontuszem wiąże się też zdobiona szamerunkiem i guzami czamara. W wieku xviıI ubiór ten mający kilkusetletnią tradycję noszenia go w Polsce, był powszechnie ubierany i uważany za narodowy strój polski na równi z kontuszem. Rola czamary wzrosła zwłaszcza po 1863 roku gdy, funkcjonowała jako ubiór powstańczy. Jej noszenie nawet przez osoby nie związane bezpośrednio z powstaniem było swoistym wyrazem uczuć patriotycznych. Warto wspomnieć też o innych elementach stroju, które mając konotacje historyczne, a pojawiały się na portretach i fotografiach ziemian. Były to na przykład delia - rodzaj obszernego płaszcza podbitego futrem i zapinanego na ozdobne guzy, haftki lub pętlice. Delię można było zarówno zakładać na ręce (jeśli rękawy były do tego dostosowane) jak i zarzucać na ramiona spinając pod szyją fibulą. Inny wierzchni strój to ferezja. Te, używane w Polsce, miały niskie kołnierze i odrzucone do tyłu dekoracyjne rękawy. Wspomnieć można też o szubie - jednym z najstarszych ubiorów noszonych w Polsce. Znana była już w XIV wieku. Był to rodzaj peleryny podbity futrem i zapinanej z przodu na pętlice lub guzy. Od wieku xv był to ubiór na tyle reprezentacyjny, że nie gardził nim nawet monarcha ${ }^{4}$.

4 Czamary, „Magazyn mód i Nowości Dotyczących Gospodarstwa Domowego", nr 22: 1861, s. 12; B. Biedrońska-Słotowa, Polski ubiór narodowy zwany kontuszowym, Kraków 2005, passim; Polaków portret własny, red. M. Rostworowski, Warszawa 1986, passim; M. Gutkowska Rychlewska, Historia ubiorów, Wrocław 1968, s. 269-306, 375-422, 499-528; D. Poppe, Szuba w ubiorze średniowiecznym w Polsce i na Rusi, Warszawa, 1998; A. Sieradzka, Tysiąc lat ubiorów w Polsce, Warszawa 2003; M. Tyszycka, Polskie pasy kontuszowe, Kraków 1995, 
Niezaprzeczalnie jednak to właśnie kontusz zrobił największą „karierę" przyjmując miano narodowego stroju polskiego. W 1776 wyszła ustawa określająca sposób noszenia się wszelkich stanów. Odnosiło się to także do stroju jaki szlachta powinna stosować będąc przedstawicielami ziem na sejmikach i w czasie publicznych wystąpieniach5 Ustanowiony zostaje zetem mundur wojewódzki inaczej zwany kontuszem mundurowym ${ }^{6}$. W 1777 określone zostały precyzyjnie barwy mundurów wojewódzkich, gdzie barwy uzależnione były od ziem jakie dany delegat reprezentował. Wprowadzenie swoistego umundurowania było z założenia jasnym wykorzystaniem stroju dla przekazu symbolicznego ${ }^{8}$.

W okresie zaborów noszenie kontusza, stało się namiastką polskości. Nie było to jednak całkowicie możliwe we wszystkich trzech zaborach. Nakazy wydane przez władze w zaborze rosyjskim uniemożliwiały zakładanie tego stroju. Czasem starano się obejść ten zakaz ale wyłącznie w trakcie uroczystości rodzinnych. W Galicji natomiast noszony był chętnie i powszechnie, zwłaszcza po wydanych zakazach carskich w sąsiednim zaborze. Miało to poniekąd swoje uzasadnienie $\mathrm{w}$ toczonej już od XvıII wieku społecznej batalii pomiędzy tradycją „noszenia się” po polsku (czyli w kontuszu) a bardziej kusymi męskimi ubiorami rodem z zachodu. Uważano, że mężczyzna, który zakłada

passim; T. Jeziorowski, A. Jeziorkowski, Mundury wojewódzkie Rzeczypospolitej Obojga Narodów, Warszawa 1992, passim; L. Zachuta, Zawieszenie białej broni, Kraków 1992, passim; I. Turnau, Ubiór narodowy w dawnej Rzeczypospolitej, Warszawa 1991, s. 19.

5 Obiaśnienie legis sumptuariae, [w:] Volumina Legum, Przedruk zbioru praw staraniem Xx. Pijarow w Warszawie, od roku 1732 do roku 1782, wydanego, t. 8, Petersburg 1860, passim.

6 Co prawda w samej ustawie nie było mowy o tym że ma to być bezwzględnie kontusz, ale to właśnie on wszedł niejako naturalnie jako podstawowy krój munduru wojewódzkiego.

7 T. Jeziorowski, A. Jeziorkowski, Mundury wojewódzkie..., s. 24-32.

8 Co prawda początkowo systematycznie wprowadzane zdobienia i przepych mundurów zakłócał czytelność znaku, jednak ustawa z 1780 roku dość skutecznie powstrzymała zapędy zbytku w stroju. 
nader obcisłe culotte, nosi przydługie włosy i goli zarost nie jest zdolny stawać w obronie ojczyzny. Narusza też takim strojem naturalny podział między płciami - długie włosy to był wyłączny atrybut kobiety, zaś pozbycie się zarostu (czyli atrybutu męskości) gruntowało jedynie „zniewieściały” wydźwięk całego stroju. Zmieniająca się moda w całej Europie spowodowała jednak, że od XIX wieku kontusz przestał być ubiorem codziennym, a stał się bardziej kostiumem, nadal jednak chętnie zakładanym w czasie ważnych chwil dla narodu, kraju, społeczeństwa czy rodziny. Nadal też pełnić on będzie istotna funkcję znaku9.

Zwłaszcza ziemianie czuli się w obowiązku zakładać go w trakcie największych wydarzeń i obchodów o charakterze narodowym i historycznym. Szczególnie wiele mężczyzn ubranych w kontusze widać było na przykład w trakcie obchodów z okazji rocznicy bitwy pod Grunwaldem. Obchody te, niejako ogłosił na łamach „Czasu” swoim artykułem Marian Dubiecki już w 1902 roku. Niebawem powołano Krajowy Komitet Obchodów Rocznicy Grunwaldzkiej. Zjazd Grunwaldzki w Krakowie odbył się 15-17 lipca 1910 roku, a wszystkie towarzyszące mu wydarzenia (np. odsłonięcie pomnika Grunwaldzkiego na placu Matejki) był okazją do manifestowania polskości i dążeń narodowowyzwoleńczych ${ }^{10}$. Tak wspomina swojego ojca w czasie

9 T. Jeziorowski, A. Jeziorkowski, Mundury wojewódzkie Rzeczypospolitej Obojga Narodów, Warszawa 1992, passim; J. Możdżeń, Mundury wojewódzkie a renesans polskiego stroju narodowego w epoce stanisławowskiej, „Sensus Historiae", nr 4:2011, z.3, s. 11-31; W. Woźnowski, Literacki spór o tradycje w czasach Stanistawa Augusta ( $Z$ dziejów motywu wąsów, kontusza i fraka), „Zeszyty Naukowe Uniwersytetu Jagiellońskiego. Prace Historycznoliterackie", z. 21:1971, s. 27-47; I. Turnau, Ubiór narodowy..., s. 161; A. Sieradzka, Ostatni Sarmaci. Polski strój narodowy w końcu XIX $i$ w 1. połowie XX w., [w:] Ubiory w Polsce. Materialy III Sesji Klubu Kostiumologii i Tkaniny Artystycznej przy Oddziale Warszawskim Stowarzyszenia Historyków Sztuki, Warszawa 1992, s. 96-105; L. Nalewajska, Moda męska w XIX i na początku xx wieku, Warszawa 2010, s. 177-183; E. Orlińska-Mianowska, Po sarmacku - strój „narodowy” kontra "cudzoziemski", [w:] Pod wspólnym niebem. Rzeczypospolita wielu narodów, wyznań, kultur (XVI-XVIII w.), Warszawa 2012, s. 211-219.

10 Kongres Kultury Polskiej 11-13 grudnia 1981, Warszawa 2000, passim. 
obchodów rocznicowych Kinga z Trzecieskich Moysowa: Miał żupan ze srebrnej lamy, granatowy kontusz z wylotami z białego atlasu, czerwone, safianowe buty, piękny pas i delie z sobolowym kotnierzem oraz taki sam kołpak. Pięknie mu w tym było i dobrze umiał ten prześliczny strój nosić. [...] Ostatni raz widziałam go mówiacego do tłumu na obchodzie 500 letniej bitwy pod Grunwaldem 14 Lipca 1910 r. na rynku w Dynowie, gdy odsłonięto tam stojacy do dziś pomnik króla Władysława Jagiełty. Miał wówczas na sobie piękny kontusz w barwach ziemi sanockiej, który tu powyżej opisałam ${ }^{11}$. Kontusze widać było także w trakcie uroczystości 250-lecia odsieczy wiedeńskiej na Kahlenbergn 13 września 1933 roku. Analogiczna sytuacja miewała miejsce również w czasie uroczystości o charakterze religijnym. W 1938 roku w trakcie uroczystości związanych ze sprowadzeniem relikwii św. Andrzeja Boboli, Andrzej Lubomirski zaprezentował się w gustownym kontuszu. Zaznaczyć w tym miejscu wypada, że szczególnie w Galicji, uroczystości religijne przybierały częstokroć formę swoistych manifestacji patriotycznych. Elementy te wydawały się mieć właściwie nierozerwalny charakter ${ }^{12}$.

Kontusze bywały strojem reprezentacyjnym także przy okazjach rodzinnych. W stroju narodowym wystąpili pan młody, ojcowie i zaproszeni goście (a przynajmniej męska ich część) na ślubie np. Katarzyny Romer i Cezarego Szoszkiewicza, Heleny i Stanisława Sierakowskich, Marii Trzecieskiej i Romana Wolskiego, Adama Michała Józefa Czartoryskiego i Jadwigi Stadnickiej czy Marii Stadnickiej i Stefana Świeżawskiego. Zwyczaj ten był zresztą dość powszechny i często praktykowany. W kontuszu, co oczywiste, starano się także portretować. Zaznaczyć tu należy jednak, że znacznie częściej strój

11 K. Moysowa z Trzecieskich, Pamiętnika. Wspomnienia z mojego dziecinstwa, http://www.witkowscy.net/marychna/index.php?option=com_content\&task=view\&id=18\&Itemid=1 [ 15 XII 2013] .

12 S. Estreicher, Znaczenie Krakowa dla życia narodowego polskiego w ciagu XIX wieku, [w:] Kraków XIX wieku, t. 1, Kraków 1932, s.17; Ł. Krzywka, Portret $w$ stroju polskim od końca XVIII do początku Xx wieku, "Studia muzealne”, z. 14:1984, s. $65-79$. 
narodowy przywdziewali w wymienionych okolicznościach mężczyźni niż kobiety. Chlubnym wyjątkiem może tu być np. strój ślubny Teodory z Giebułtowskich Matejkowej, w którym zresztą została sportretowana przez swojego znanego małżonka ${ }^{13}$.

Sytuacja taka miała być może związek z nieco inaczej kształtującą się historią stroju narodowego w wersji damskiej. Kobiety demonstrowały bowiem uczucia narodowe nosząc, w latach 1861-1866, tzw. żałobę narodową. Żałobny charakter stroju damskiego pojawiał się potem w kolejnych latach, jako manifestacja uczuć patriotycznych. Owszem istniały także, propagowane zresztą przez żurnale i pisma kobiece, np. kontusiki lub polonezki z jupką (widać je np. na zdjęciu Marii Billewicz, późniejszej matki marszałka J. Piłsudskiego). Częściej jednak używano je jako kostiumy niż stroje codzienne lub uroczyste - choć takie też oczywiście się zdarzały ${ }^{14}$.

Najpowszechniejszy wśród pań strój używany w czasie żałoby narodowej mniej nadawał się do zakładania go w czasie szczególnie uroczystych okoliczności rodzinnych (np. ślubu). Strój kobiecy w tym okresie składał się z czarnej zabudowanej sukni (najczęściej na krynolinie), której jedyną „barwną” ozdobą były białe mankiety i takiż kołnierz. Dozwolone było ewentualne stosowanie ciemnych fioletów, jako alternatywnego dla czerni koloru żałobnego. Dekoracją oprócz stosownej biżuterii (o czym poniżej) mogły być czarne hafty o motywach patriotycznych, np. wyhaftowany na piersi orzeł, zakryty czarnym muślinem ${ }^{15}$.

13 Ziemianie. Pomiędzy..., passim.

14 Mierosławka..., kontusz i żupan, „Dziennik Mód Paryskich”, nr 25:1848, s. 204; Ubiory niewiast tegoroczne, „Tygodnik ilustrowany”, nr 85:1861, s. 179; Strój narodowy, „Dziennik Mód Paryskich”, nr 21:1848, s.172.

15 M. Możdżyńska-Nawotka, Żałoba narodowa: rozpięta między moda, obyczajem a historia, „Zabytki - Heritage”, http://kultura.wp.pl/kat,98354,title,Zaloba-narodowa-rozpieta-miedzy-moda-obyczajem-a-historia,wid,10508 699,wiadomosc.htm [27 XII 2013]. 
Warto wspomnieć jeszcze o jednym stroju, będącym swoistym ewenementem kulturowym. Na przełomie xIx i xx pod wpływem młodopolskich fascynacji, popularne staje się dla zamanifestowania polskości, używanie krakowskiego (rzadziej także podhalańskiego) stroju ludowego lub jego stylizacji. W tzw. stroje ludowe przebierały się zwłaszcza osoby z wyższych warstw społeczny. Popularny był także wśród artystów. Strój krakowski był wzorem do przebrań na bale lub kuligi. Pojawiła się też moda ubierania służby w stylizowane stroje krakowskie jako liberie. Moda na krakowiańszczyznę wiązała się nie tylko z przekonaniem, że to właśnie w warstwach chłopskich należy szukać odrodzenia narodowego; miała ona także swoje konotacje $\mathrm{z}$ tradycją kościuszkowską a więc walką narodowowyzwoleńczą ${ }^{16}$.

Nieodłącznym elementem stroju jest biżuteria. Tradycja biżuterii patriotycznej w Polsce sięga XvıII wieku. Pierwsze jej przykłady wiązać należy z konfederacją barską. Z tego okresu zachowały się np. pierścienie z ośmiokątnym okiem z krwawnika, na którym widniał napis: „Pro lege et patria” i „Pro fide et Maria”. Były to hasła konfederatów odrzucające dewizę orderu Orła Białego („Pro fide rege et lege”). Biżuteria patriotyczna przybierała wiele form. Zwykle nie były to przedmioty arcykosztowne. Ich wartość wyrażała się bardziej w znaku, symbolu jakim były. Obok wisiorków, zegarków, kolczyków, bransolet i pierścieni, sygnetów lub obrączek, znajdziemy także klamry do pasków, spinki do mankietów czy odznaki wpinane w klapę. Popularne są także biało czerwone kokardy lub rozety. Szczególne miejsce w biżuterii tego typu zajmuje jednak pierścień lub obrączka. Od starożytności pierścień uważany był za element szczególny - wręcz magiczny. Przypisywano im moc uzdrawiania, ochrony lub mocy. Zwykle wiązał się z symboliką miłości, wierności i pamięci. Mógł być także insygnium

16 J. Kamocki, Przyczyna rozpowszechniania się ubioru krakowskiego jako stroju narodowego, „Polska Sztuka Ludowa”, R. 30:1976, nr 2. s. 75-78; A. Kowalska-Lewicka, Ludowy strój krakowski - strojem narodowym, „Polska Sztuka Ludowa”, R. 30: 1976, nr 2; J. Burszta, Kultura ludowa - kultura narodowa, Warszawa 1974, passim. 
władzy, piastowanej godności lub znakiem przynależności rodowej. W biżuterii patriotycznej stał się odznaką za zasługi dla ojczyzny, znakiem rozpoznawczym dla organizacji spiskowych, a także emblematem narodowym, symbolem haseł i myśli patriotycznych. Stanowił formę upamiętnienia wydarzeń patriotycznych, rocznic historycznych lub dążeń narodowych. Spotkać można zatem nie tylko obrączki lub pierścienie z godłem Polski lub portretami bohaterów narodowych ale i z wyrytymi napisami, np. „Fides manibus”, „Ojczyzna obrońcy swemu”, „Boże wspieraj wiernych Ojczyźnie” „Polska żyje”, „Książe P. Józef Poniatowski” i szereg innych. Dużą grupę stanowią te, z motywami symbolicznymi. Oprócz popularnych znaków, omówionych poniżej, na pierścieniach można było znaleźć także bardziej ukryty znaczeniowo przekaz. Na sygnetach tajnych związków w XIx wieku wyryte były np. waga lub oko, ucho i usta jako swoisty nakaz obserwowania, słuchania i milczenia. Po powstaniu listopadowym modne stały się sygnety z ukrytym schowkiem, w którym umieszczany był patriotyczny symbol (godło Polski, symbol - np. postać kosyniera lub jakaś sentencja $)^{17}$.

Podstawowym motywem powtarzającym się w biżuterii patriotycznej były symbole narodowe: Orzeł polski i barwy narodowe. Wygląd orła zmieniał się oczywiście zależnie od czasów, stanowiąc aktualną formę Godła Polskiego lub odnosząc się do jego historycznych form, zwłaszcza z okresu świetności Rzeczypospolitej. W xıx wieku częstym motywem jest także tarcza z godłem Polski i Litwy (orzeł i pogoń) lub Polski, Litwy i Rusi (orzeł, pogoń i Archanioł Michał). Dość charakterystycznym motywem było połączenie wizerunku orła z motywem odnoszącym się do zniewolenia Polski lub walki i nadziei na jej oswobodzenie. Mógł to być np. orzeł zrywający kajdany lub orzeł w koronie na tle krzyża

17 W. Bigoszewska, Polska biżuteria patriotyczna, Warszawa 2003, passim; Polska biżuteria patriotyczna, red. T. Skoczek, K. Duda, P. Bezak, Warszawa 2011, passim; L. Gintowt-Dziewałtowska, Polska biżuteria patriotyczna, Warszawa 1980, passim; M. Gorżkowski, Cymeliarchium. Historyczne poszukiwania nad znaczeniem obrączki i pierścionka, Kijów 1864, passim. 
i gałązki laurowej co symbolizowało sławę, zwycięstwo, wolność, prawdę i pokój. Motywami wiążącymi się z treściami narodowowyzwoleńczymi były także kajdany i łańcuchy (często noszono bransolety lub naszyjniki w formie łańcucha), kosa (albo kosynier), która kojarzyła się powstaniem kościuszkowskim lub kotwica, która przez wiele wieków była uniwersalnym symbolem nadziei na zwycięstwo. Swoistą manifestacją przekonań było umieszczanie na biżuterii portretów bohaterów narodowych. Przoduje tu oczywiście wizerunek Tadeusza Kościuszki. Można jednak też znaleźć portrety Józefa Poniatowskiego, Jana Dąbrowskiego, Józefa Sowińskiego, Adama Czartoryskiego, Adama Mickiewicza a nawet króla Jana II Sobieskiego. Można także spotkać w późniejszym okresie wizerunki lub inicjały Józefa Piłsudskiego ${ }^{18}$.

Równie dużą popularność zyskały sobie symbole religijne. Najczęstszym był oczywiście krzyż lecz pojawiały się także inne symbole np. korona cierniowa - znak cierpienia zarówno Chrystusa jak i współcierpienia z Nim lub liść palmowy symbolizujący męczeństwo. Symbole religijne odnoszące się do treści pasyjnych lub męczeństwa łączono z ideą umęczonej Polski i cierpiącego narodu. Dość częstym motywem były także symbole mariologiczne i wizerunki Matki Boskiej. Bardzo mocno na ziemiach Polskich zakorzeniony kult maryjny ${ }^{19}$ spowodował, że wizerunki Matki Boskiej Częstochowskiej lub Ostrobramskiej uważane były właściwie za symbole narodowe. Dość popularnymi są także symbole odnoszące się do cnót teologalnych: wiary, nadziei i miłości. Zwykle są to krzyż, kotwica i serce. Zaznaczyć należy, że także te przed-

18 J. J. Dreścik, „Od zwątpiałości do najpiękniejszej otuchy”. Pamiątki żałoby narodowej z 1809 roku, [w:] Treści - teksty przesłania. Biżuteria w Polsce, red. K. Kluczwajd, Toruń 2006, s. 103-106; B. i Z. Dolczewscy, „Oblubienica Ojczyzny”, czyli patriotyczna biżuteria Działyńskich [w:] Biżuteria w Polsce. Amulet, znak, klejnot, red. K. Kluczwajd, Toruń 2003, s. 86-93; W. Bigoszewska, Polska biżuteria..., s. 10.

19 Tradycja tytułu Marii Królowej Polski sięga Xvi wieku, jednak Maryja ogłoszona został oficjalnie Królową Polski dnia 1 kwietnia 1656 roku w czasie ślubów króla Jana Kazimierza, które złożył w katedrze Lwowskiej. 
stawienia odnosiły się nie tylko do treści religijnych ale także odczuć patriotycznych, np. nadzieję lub wiarę wiążąc z oczekiwaniem na odzyskanie niepodległości a miłość z miłością do ojczyzny. Wyraźnie zatem widać nierozerwalność i swoisty dualizm symboli narodowych i religijnych, które wzajemnie się uzupełniając dają właściwy przekaz symboliczny zawierający się w chyba najbardziej znanym haśle „Bóg Honor - Ojczyzna"2o.

Po upadku powstania listopadowego popularna stała się biżuteria z umieszczonymi w niej swoistymi relikwiami. Przykładem mogą być krzyże z Olszynki Grochowskiej. Wykonane one były z drewna olchowego i delikatnych okuć ze złota lub mniej szlachetnego metalu. Najczęściej posiadały napis np. „z Olszynki - 25 lutego 1831”. Po powstaniu styczniowym pojawiają się także elementy biżuterii będące formą relikwii. Najczęściej były one wykonywane przez więźniów politycznych z Cytadeli, Ołomuńca lub tych zesłanych na Sybir. Były to np. obrączki zrobione z włosia z napisem „Pamiątka niewoli” lub „Pamiątka Rewolucji Polskiej 1863”. Mogły to też być krzyżyki z drewna, kości zwierzęcych lub nawet słomy. Zaznaczyć należy, że właściwie cała biżuteria patriotyczna z czasem, nabrała cech relikwii. Jak wspomniano, rzadko jest to biżuteria cenna materialnie. Są to jednak bezcenne pamiątki, których przechowywanie do dziś w wielu rodzinach, jest swoistym pielęgnowaniem pamięci o przodkach, którzy oddawali swoje siły, pracę a nawet życie dla dobra Rzeczypospolitej ${ }^{21}$.

Po analizie portretów i fotografii portretowych ziemian polskich nasuwa się jeszcze jeden wniosek. Istotnym elementem w przekazie

20 S. Chmielewski, Polska bizuteria patriotyczna i problem komunikacji interpersonalnej, [w:] Biżuteria w Polsce. Amulet, znak, klejnot, red. K. Kluczwajd, Toruń 2003, s. 80-84; W. Okoń, Polska biżuteria patriotyczna, [w:] Pod zaborami 1795-1914, red. M. Derwich, Warszawa-Wrocław 2003, s. 128-129; E. Piwocka, Zbiór biżuterii patriotycznej Muzeum Historycznego m. st. Warszawy. Problemy datowania i atrybucji, [w:] Rzemiosło artystyczne $i$ wzornictwo w Polsce. Biżuteria w Polsce, red. K. Kluczwajd, Torun 2006, s. 117-128.

21 W. Bigoszewska, Polska biżuteria..., s. 61, 109. 
semantycznym był nie tylko sam strój i biżuteria ale także rekwizyty. Treści przekazywane w ten sposób można podzielić na kilka grup. Najczęstsze odniesienia miały oczywiście charakter narodowo-patriotyczny. Mógł to być np. portrety przodków, gdzieś w głębi pokoju, biżuteria patriotyczna po przodkach (nawet nie koniecznie założona) lub tak jak na znanym zdjęciu Cecylii z Potockich Reyowa, która pochylając się nad synami pokazuje im szablę, którą ich przodkowie dzierżyli w ręku stając w obronie ojczyzny. Można wspomnieć w tym miejscu także dość popularne „żywe obrazy”. Oczywiście nie wszystkie posiadały poważny wydźwięk, zachowały się jednak także takie, które nawiązywały np. do Trylogii sienkiewiczowskiej lub tradycyjnych symboli narodowych. Dość oczywiste były odniesienia religijne. Najpopularniejszym rekwizytem na portretach kobiet jest zatem trzymany w ręku modlitewnik. Znajdziemy też bez trudu przykłady rekwizytów mających na celu pokazanie wagi nauki i sztuki. Portretowanie się przy pianinie (nawet jeśli nie był to instrument służący portretowanej osobie do gry) lub przy otwartej książce były powszechnym zwyczajem²2.

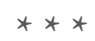

Nie jest moim celem ukazywanie ziemian polskich jako osób myślących jedynie o Rzeczypospolitej, narodzie i wierze. I to zarówno w chwili podejmowania ważkich dl Ojczyzny decyzji jak i w chwilach decydowania o odpowiednim strojem. Ziemianie byli i są normalnymi ludźmi, którzy pracują, bawią się, świętują, czasem płaczą, czasem się złoszczą lub podejmują niewłaściwe decyzje... jak każdy. Jest to jednak specyficzna grupa społeczna, dla której poczucie polskości i dumy - także tej narodowej - stanowi ważny element życia.

„Nam strój niedbały nie przystoi” - no przecież!

22 Ziemianie. Pomiędzy..., passim; Nam ubiór niedbały nie przystoi. Katalog wystawy, oprac. L. Król, M. Skrejko, Kraków 2003, passim. 


\section{Bibliografia}

Bartkiewicz M., Odzież i wnętrza domów mieszczańskich w Polsce $w$ drugiej połowie XVI i w XVII wieku, Wrocław-Warszawa-Kraków-Gdańsk 1974.

Bartkiewicz M., Polski ubiór do 1864 roku, Wrocław 1979.

Biedrońska-Słotowa B., Polski ubiór narodowy zwany kontuszowym, Kraków 2005.

Bigoszewska W., Polska biżuteria patriotyczna, Warszawa 2003.

Burszta J., Kultura ludowa - kultura narodowa, Warszawa 1974.

Chmielewski S., Polska biżuteria patriotyczna i problem komunikacji interpersonalnej, [w:] Biżuteria w Polsce. Amulet, znak, klejnot, red. K. Kluczwajd, Toruń 2003, s. 80-84.

Czamary, „Magazyn mód i Nowości Dotyczących Gospodarstwa Domowego", nr 22: 1861, s. 12.

Dolczewscy B. i Z., „Oblubienica Ojczyzny”, czyli patriotyczna biżuteria Działyńskich [w:] Biżuteria w Polsce. Amulet, znak, klejnot, red. K. Kluczwajd, Toruń 2003, s. 86-93.

Dreścik J. J., „Od zwątpiałości do najpiękniejszej otuchy”. Pamiątki żałoby narodowej z 1809 roku, [w:] Treści - teksty przesłania. Biżuteria $w$ Polsce, red. K. Kluczwajd, Toruń 2006, s. 103-106.

Estreicher S., Znaczenie Krakowa dla życia narodowego polskiego w ciagu XIX wieku, [w:] Kraków XIX wieku, t.1, Kraków 1932.

Gintowt-Dziewałtowska L., Polska biżuteria patriotyczna, Warszawa 1980.

Gorżkowski M., Cymeliarchium. Historyczne poszukiwania nad znaczeniem obrączki i pierścionka, Kijów 1864.

Gutkowska Rychlewska M., Historia ubiorów, Wrocław 1968.

Jeziorowski T., Jeziorkowski A., Mundury wojewódzkie Rzeczypospolitej Obojga Narodów, Warszawa 1992.

Kamocki J., Przyczyna rozpowszechniania się ubioru krakowskiego jako stroju narodowego, „Polska Sztuka Ludowa”, R. 30: 1976, nr 2. s. 75-78.

Kongres Kultury Polskiej 11-13 grudnia 1981, Warszawa 2000. 
Kowalska-Lewicka A., Ludowy strój krakowski - strojem narodowym, „Polska Sztuka Ludowa”, R. 30: 1976, nr 2.

Krzywka Ł., Portret w stroju polskim od końca XVIII do początku XX wieku, „Studia muzealne”, z. 14:1984, s. 65-79.

Mierosławka..., kontusz i żupan, „Dziennik Mód Paryskich”, nr 25:1848, s. 204.

Moysowa z Trzecieskich K., Pamiętnika. Wspomnienia z mojego dziecinstwa, http://www.witkowscy.net/marychna/index.php?optio$\mathrm{n}=$ com_content\&task $=$ view\&id $=18$ \&Itemid $=1$ [15 XII 2013] .

Możdżeń J., Mundury wojewódzkie a renesans polskiego stroju narodowego w epoce stanisławowskiej, „Sensus Historiae”, nr 4:2011, z.3, s. 11-31.

Możdżyńska-Nawotka M., Żałoba narodowa: rozpięta między moda, obyczajem a historia, „Zabytki - Heritage”, http://kultura.wp.pl/kat,98354,title,Zaloba-narodowa-rozpieta-miedzy-moda-obyczajema-historia,wid,10508699,wiadomosc.htm [27 XII 2013].

Nalewajska L., Moda męska w XIx $i$ na początku xx wieku, Warszawa 2010.

Nam ubiór niedbały nie przystoi. Katalog wystawy, oprac. L. Król, M. Skrejko, Kraków 2003.

Obiaśnienie legis sumptuariae, [w:] Volumina Legum, Przedruk zbioru praw staraniem xx. Pijarow $w$ Warszawie, od roku 1732 do roku 1782, wydanego, t. 8, Petersburg 1860.

Okoń W., Polska biżuteria patriotyczna, [w:] Pod zaborami 1795-1914, red. M. Derwich, Warszawa-Wrocław 2003, s. 128-129.

Orlińska-Mianowska E., Po sarmacku - strój „narodowy” kontra „cudzoziemski", [w:] Pod wspólnym niebem. Rzeczypospolita wielu narodów, wyznań, kultur (XVI-XVIII w.), Warszawa 2012, s. 211-219.

Piwocka E., Zbiór biżuterii patriotycznej Muzeum Historycznego m. st. Warszawy. Problemy datowania i atrybucji, [w:] Rzemiosło artystyczne i wzornictwo w Polsce. Bizuteria w Polsce, red. K. Kluczwajd, Toruń 2006, s. 117-128.

Polaków portret własny, red. M. Rostworowski, Warszawa 1986. 
Polska biżuteria patriotyczna, red. T. Skoczek, K. Duda, P. Bezak, Warszawa 2011.

Poppe D., Szuba w ubiorze średniowiecznym w Polsce i na Rusi, Warszawa, 1998.

Rotter L., Leksykon strojów i mundurów bractw kurkowych w Polsce, Kraków 2011.

Rotter L., Ubiór jako wyróżnik przynależności do związków i organizacji na przykładzie bractw kurkowych [w:] Znak, symbol a rituál ako forma společnej komunikácie, Prešov 2012, s. 119-140.

Sieradzka A., Ostatni Sarmaci. Polski strój narodowy w końcu XIX i w 1. połowie XX w.,[w:] Ubiory w Polsce. Materiały III Sesji Klubu Kostiumologii i Tkaniny Artystycznej przy Oddziale Warszawskim Stowarzyszenia Historyków Sztuki, Warszawa 1992, s. 96-105.

Sieradzka A., Tysiąc lat ubiorów w Polsce, Warszawa 2003.

Strój narodowy, „Dziennik Mód Paryskich”, nr 21:1848, s.172.

Turnau I., Odzież mieszczaństwa warszawskiego w XVIII w., Wrocław-Warszawa-Kraków 1967.

Turnau I., Ubiór narodowy w dawnej Rzeczypospolitej, Warszawa 1991. Tyszycka M., Polskie pasy kontuszowe, Kraków 1995.

Ubiory niewiast tegoroczne, „Tygodnik ilustrowany”, nr 85:1861, s. 179.

Woźnowski W., Literacki spór o tradycje w czasach Stanisława Augusta ( $Z$ dziejów motywu wąsów, kontusza i fraka), „Zeszyty Naukowe Uniwersytetu Jagiellońskiego. Prace Historycznoliterackie”, Z. 21:1971, s. 27-47.

Zachuta L., Zawieszenie białej broni, Kraków 1992.

Ziemianie. Pomiędzy rzeczywistością a wspomnieniem, oprac. A. Wolska, Kraków 1998. 


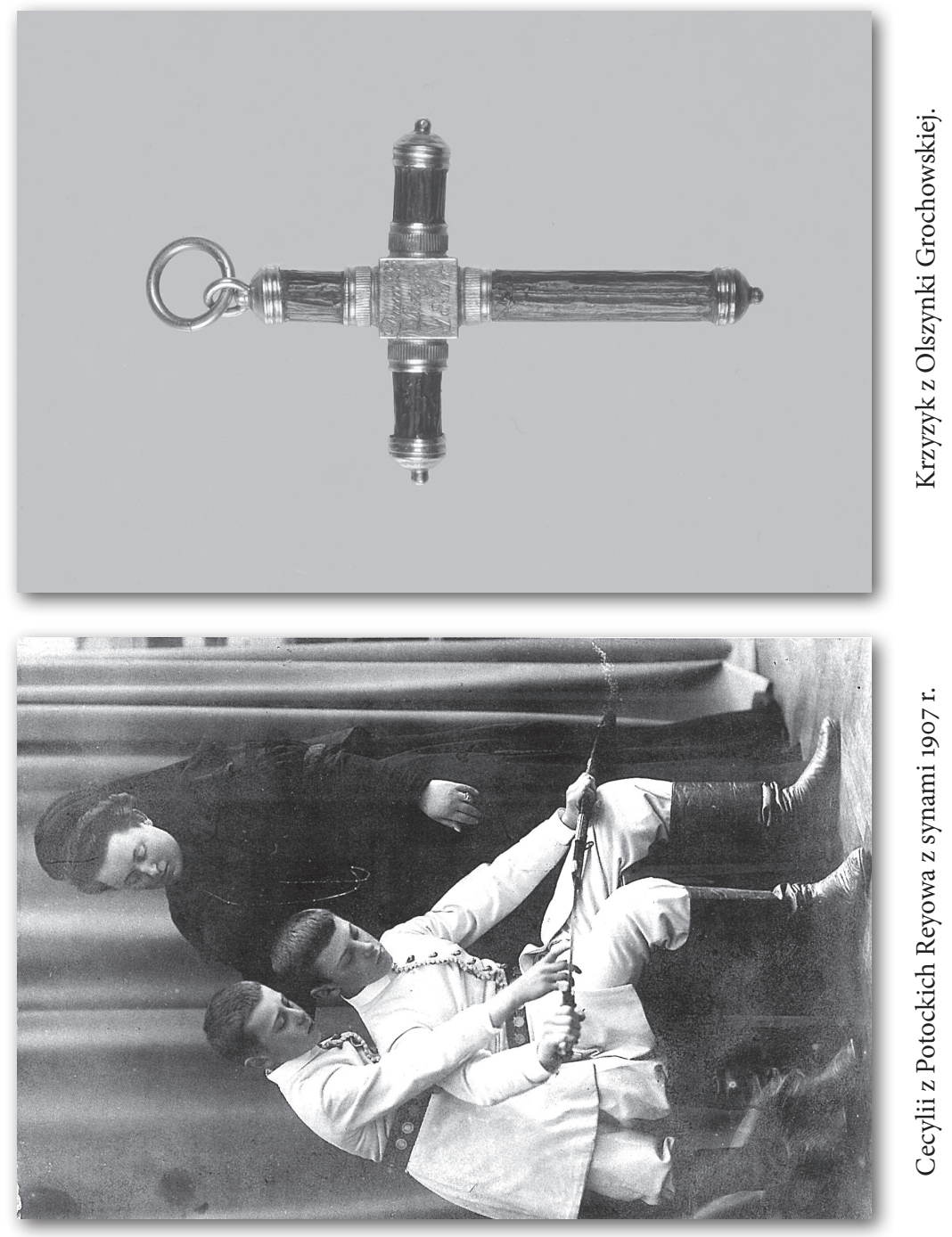






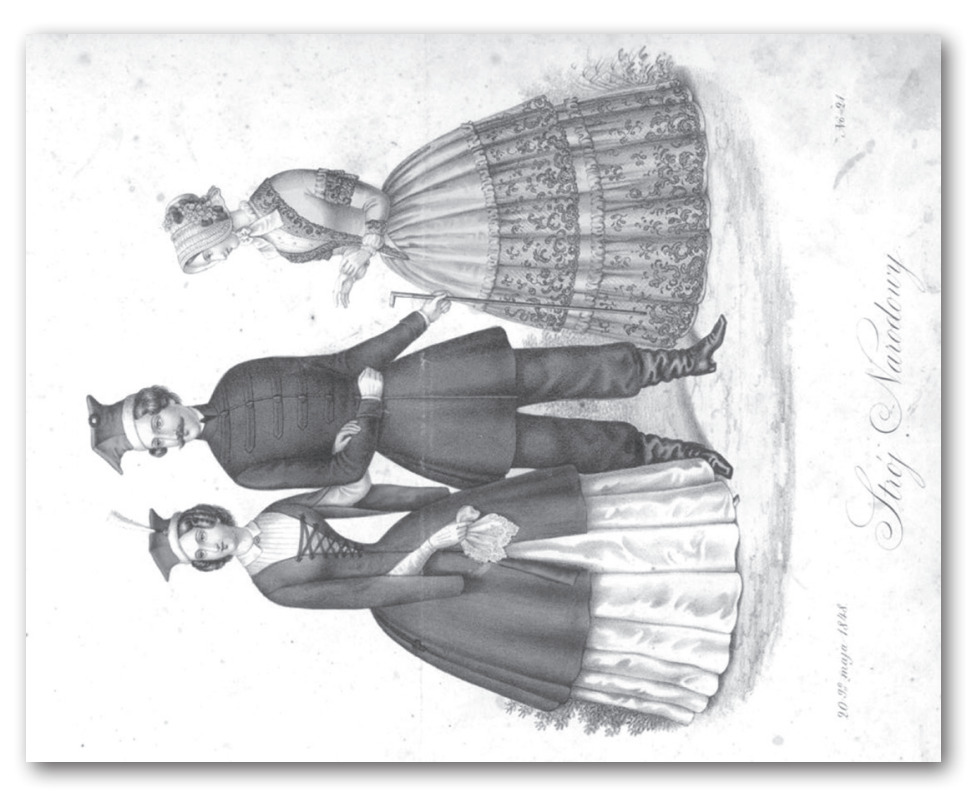

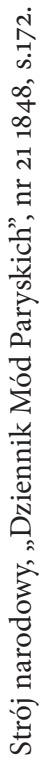
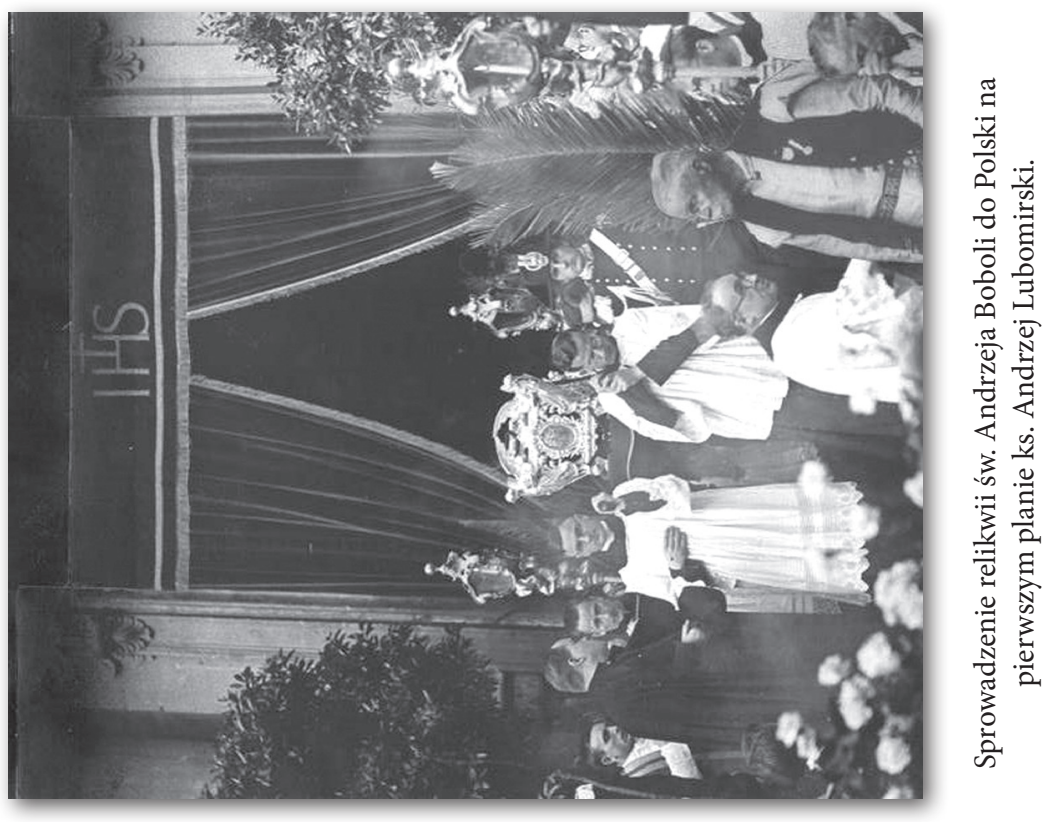


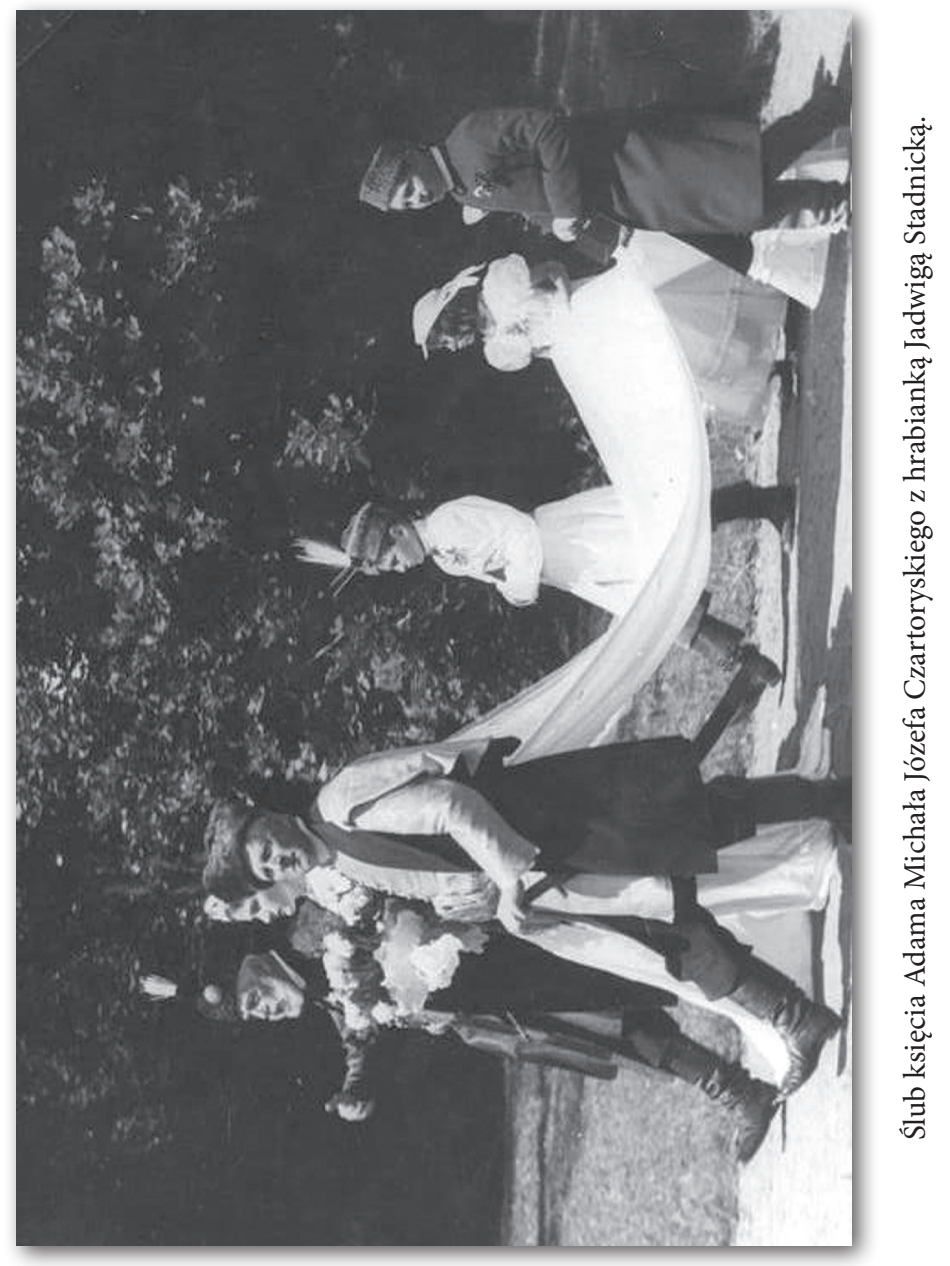

